\title{
Helminth parasites of grey mullets (Teleostei: Mugilidae) in the Mediterranean region: a review
}

\author{
Sarabeev V. L., Tkach Ie. V. \\ ORCID ID: 0000-0003-4724-3141 \\ Zaporizhzhia National University, Ukraine \\ volodimir.sarabeev@gmail.com
}

Key words:

Mediterranean and Azov-Black

Seas, Mugil cephalus,

Chelon labrosus, Chelon auratus,

Chelon ramado, Chelon saliens,

Planiliza haematocheila
Helminths are a diverse and rich group of fish parasites, some of which are dangerous pathogens of epidemic potential. The present review is focused on helminth parasites from grey mullets (Mugilidae) in the Mediterranean and Azov-Black Seas. These fish are of great economic importance, for supplying food and recreation services. This study covers helminth parasites of six species: Mugil cephalus (L.), Chelon labrosus (Risso), C. auratus (Risso), C. ramado (Risso), C. saliens (Risso) and Planiliza haematocheila (Temminck, Schlegel). This paper gives a brief overview of the history of taxonomic and faunistic studies of helminth parasites from grey mullets in the Mediterranean. The history of the helminth parasites from grey mullets goes back to over 200 years ago to the first species described by Rudolphi in 1819. One hundred and four helminth species have been recorded in about 130 published papers. Fewer than 10 species have been recorded prior to 1900. Since 1960s, taxonomic efforts have rapidly increased, reaching the highest level in the first decade of the 21 st century. Only one new species has been recorded in Mediterranean mullets in the last decade. We suggest that the decrease in the number of described species observed in the last decade is the consequence of previous intensive taxonomic efforts result in actual estimation of species diversity for the studied area. Digeneans and specialist (oioxenic and stenoxenic) parasites dominated in the structure of helminth fauna of mullets. The highest richness of helminths is found in the Azov-Black Seas mullets, while the poorest in the Eastern Mediterranean. A relatively large number of species (20) identified only to generic or family levels remain the taxonomic subject of future studies.

\section{Гельмінти кефалей (Teleostei: Mugilidae) Середземноморського регіону: літературний огляд}

Сарабєєв В. Л., Ткач Є.В.

Запорізький національний університет, Украӥна

\section{Ключові слова:}

Середземне море,

Азово-Чорноморський регіон, Mugil cephalus, Chelon labrosus, Chelon auratus, Chelon ramado,

Chelon saliens,

Planiliza haematocheila

\begin{abstract}
Гельмінти - різноманітна і багата група паразитів риб, серед яких $\epsilon$ небезпечні збудники захворювань, що можуть призводити до масових епізоотій серед популяцій риб. Огляд присвячено гельмінтам кефалевих риб (Mugilidae), що мешкають у водах Середземного та АзовоЧорноморського басейнів. Кефалі мають велике економічне значення 3 огляду на споживання та рекреацію. Дослідження охоплює огляд гельмінтів від шести видів: Mugil cephalus (L.), Chelon labrosus (Risso), $C$. auratus (Risso), C. ramado (Risso), C. saliens (Risso) та Planiliza haematocheila (Temminck, Schlegel). Наведено стислий огляд історії таксономічних та фауністичних досліджень паразитів гельмінтів від кефалей у Середземномор'ї. Історія вивчення гельмінтів кефалей сягає понад 200 років та бере початок від опису акантоцефали, виконаного Рудольфі в 1819 році. Сто чотири види гельмінтів було відзначено у близько 130 опублікованих працях. До 1900 року було зареєстровано
\end{abstract}


менше ніж 10 видів, переважно досить великих. Із 1960-х років таксономічні зусилля дослідників гельмінтів кефалей швидко зростали, сягнувши найвищого рівня в першій декаді XXI століття (описано 13 нових видів). Але за останнє десятиріччя було виявлено та описано лише один новий вид гельмінтів від кефалей. Ми припускаємо, що зменшення кількості описаних видів, що спостерігалося протягом останнього десятиріччя, $€$ наслідком попередніх інтенсивних таксономічних зусиль. Імовірно, це призвело до фактичної оцінки різноманітності видів для досліджуваної території. У структурі гельмінтофауни переважають дигенеї і специфічні паразити. Найбагатше різноманіття гельмінтів виявлено в Азово-Чорноморських кефалей, тоді як найбідніше - у східному Середземномор'ї. Порівняно велика кількість видів (20), визначених до родового або родинного рівня, залишають перспективи для подальших таксономічних досліджень гельмінтів кефалей.

\section{Introduction}

Helminths represent one of the most diverse group of fish parasites. Many species are dangerous pathogens of epidemic potential, that may cause serious damage in both wild and farmed animals ${ }^{1,2}$. Taxonomic and faunistic studies are the first step in ecological and epidemiological investigations and are important for discovering and documenting species diversity, their geographic distribution, host specificity and pathogenicity.

The present study focuses on a variety and number of helminth parasites from grey mullets (Mugilidae) in the Mediterranean and Azov-Black Seas. Mullets are of great economic importance ${ }^{3}$, supplying food and recreation services. The demand for mullet roe has grown considerably in recent decades elevated the status of grey mullets to be being called «grey gold» ${ }^{4,5}$. This review covers helminth parasites of six species from three genera of the Mugilidae family: flathead mullet Mugil cephalus, thicklip mullet Chelon labrosus, golden grey mullet Chelon auratus, thinlip mullet Chelon ramado, leaping mullet Chelon saliens and so-iuy mullet, also known as haarder or red-lip mullet, Planiliza haematocheila ${ }^{6}$. Oedalechilus labeo (Cuvier, 1829) also occurs in the Mediterranean ${ }^{6}$, but only one reference reports two species of flatworms from this host ${ }^{7}$. P. haematocheila was deliberately introduced in the Black and the Azov Seas. The main goal of the introduction was seeking ways to increase the fishing capacity of natural water reservoirs and to use abundant and underutilized amount of detritus $^{8}$. The fish translocation with subsequent induced breeding and fry release in the 1970s-1980s resulted in the establishment of a self-reproducing population of the so-iuy mullet in the new distribution range ${ }^{9}$. The soiuy mullet has been officially subject to commercial fishing in Ukraine since $1993^{10}$. This fish is one of the most important and common commercial fish, which is dominant in catch composition, and effectively replacing the depleted stocks of local mullets ${ }^{9,11}$.

The history of the helminth parasites from grey mullets goes back to over 200 years ago to the first species described ${ }^{12}$. The first review of the parasitic species recorded from worldwide mullets was provided by Paperna and Overstreet in $1981^{2}$. More recently, Radujković and co-authors ${ }^{7,13-16}$, and Dmitrieva and Gaevskaya ${ }^{17}$ reviewed the parasite species list of grey mullets from the Adriatic and the Azov-Black Seas, respectively. A review of microparasites, also including viral, prokaryotic, and fungal pathogens, of mullets worldwide was performed by Ovcharenko ${ }^{18}$. Thus, a review of helminth parasites of grey mullets at the large geographic scale of the Mediterranean region is needed to analyse the literature available, compile a species list, examine the structure of the helminth fauna and evaluate further perspectives. The present work is specifically designed to cater for these objectives.

\section{History of taxonomic and faunistic studies of helminth parasites from grey mullet fish in the Mediterranean and Azov-Black Seas}

It is likely that the first record of parasites from a grey mullet host was published by Rudolphi ${ }^{12}$ in 1819. Rudolphi's monograph includes a description of Neoechinorhynchus 
agilis (as Echinorhynchus agilis) from the Mediterranean flathead grey mullet. Since this first description, this acanthocephalan species has been recorded in numerous marine and freshwater locations in the Northern Hemisphere and from a broad range of host species ${ }^{15,17,19-24}$. The first description of a digenean Haplosplanchnus pachysomus (as Distoma pachysoma), one of the largest metazoan species reported from $C$. auratus (as Mugil auratus), was done by Eysenhardt ${ }^{25}$ in the early $19^{\text {th }}$ century. One species of intestinal digenean, Haploporus benedenii (Stossich, 1887) (as Distomum benedeni) and three species of ectoparasitic monogeneans, Solostamenides mugilis (Vogt, 1878) (as Microcotyle mugilis), Ligophorus vanbenedenii (Parona and Perugia, 1890) (as Tetraonchus vanbenedenii) and Benedenia monticellii (Parona and Perugia, 1895) (as Phylline monticellii) were described in the late $19^{\text {th }}$ century $^{26-28}$. The scarce information gained in $19^{\text {th }}$ century indicate that parasites of grey mullets were studied sporadically at that time (fig.1).

In the early $20^{\text {th }}$ century, Looss published two papers with description of eight new intestinal digenean species from grey mullets off the coast of Trieste ${ }^{29}$ and Egypt ${ }^{30}$. Looss ${ }^{29}$ erected four new genera (Haploporus, Dicrogaster, Saccocoelium and Lecithobothris) to allocate digeneans from Mediterranean mullets, which were later assigned to Haploporidae Nicoll, $1914^{31}$. The extent of intra- and interspecific variation in species from these four genera is virtually unknown, since most species within the genus are known only from their original descriptions. Although the Mediterranean forms of Haploporus, Dicrogaster, Saccocoelium and Lecithobothris, are the most widely reported species, there are few documented reports providing data on their morphology $y^{32-34}$. Therefore, a taxonomic review of Haploporidae was needed and this huge work has been recently done by BlascoCosta and co-authors ${ }^{32-35}$. These author reviewed Haploporus, Dicrogaster, Saccocoelium, Lecithobothris and Forticulcita Overstreet, 1982, erected a new genus, Ragaia Blasco-Costa, Montero, Gibson, Balbuena \& Aneta Kostadinova,
2009, and described six new species of haploporid digeneans.

The first record of helminth parasites from the Black Sea mullets was published by Wlassenko $^{36}$. In this work, Wlassenko registered undetected monogenean species Dactylogyrus sp. and three digeneans, including S.tensum Looss 1902, H. pachysomus and a new species of Haploporus, Haploporus longicolum (Vlassenko, 1931). Skrjabin ${ }^{37}$ erected Wlassenkotrema Skrjabin, 1956 to allocate the latter species. Yamaguti ${ }^{38}$ treated Wlassenkotrema as a junior synonym of Haploporus, while Overstreet and Curran ${ }^{39}$ considered $W$. longicolum as a synonym of S. obesum Looss 1902. Osmanov ${ }^{40}$, Chernyshenko $^{41}$, Butskaya ${ }^{42}$ and Pogoreltseva ${ }^{43}$ studied parasite fauna of the Black Sea fish, including grey mullets, extending the list of parasite fauna to eight species. The subsequent publication of Reshetnikova ${ }^{44}$ merits special attention. This work provided an analysis of faunal, as well as regional, age and seasonal dynamics of infection parameters of parasites from three grey mullet hosts across different localities in the Azov-Black Seas. Thirteen, 15 and 11 species were reported from $M$. cephalus, $C$. auratus and $C$. saliens, respectively. Based on the patterns of seasonal and age dynamics practical recommendations were given for the optimal age for introduction of grey mullets in estuaries for aquaculture exploitation ${ }^{44}$. Thus, studies of the Black Sea grey mullet parasites in the first half of the $20^{\text {th }}$ century were mostly carried out at the Caradag Biological Station, Kurortne, Crimea, Ukraine, but with Department of Ecological Parasitology, O. O. Kovalevsky Institute of Biology of the Southern Seas, Sevastopol, Ukraine in the second half of the $20^{\text {th }}$ century and up to the present time.The team of the Department of Ecological Parasitology together with the Odessa and Karadag branches published over 25 papers devoted to the parasite fauna ${ }^{17,45-63}$, taxonomy ${ }^{53,56,60,64-70}$, ecology $^{70,71}$ and pathogens ${ }^{72}$ of grey mullets of the Azov-Black Seas. Researchers of the Sevastopol's team described two monogenean species from grey mullets, Ligophorus euzeti Dmitrieva and Gerasev, 1996, and 
Polyclithrum ponticum Gerasev, Dmitrieva and Gaevskaya, 2002 $2^{53,66}$. Recently, a number of monographs published by Gaevskaya ${ }^{73-75}$ were devoted to studies of fish parasites and pathogens from the Azov-Black Seas, including parasites of grey mullets. The Black Sea mullets have also been studied along the Bulgarian $^{76,77}$ and Turkish ${ }^{78-80}$ coastal waters. These studies report new faunistic records of parasites.

Coming back to the Mediterranean, some studies of Euzet and co-authors devoted to monogenean parasites of grey mullets were published in the second half of the $20^{\text {th }}$ century $^{81-83}$. Euzet and Suriano ${ }^{82}$ erected Ligophorus within the Ancyrocephalidae (Monogenea), and included 11 species parasitizing the gills of grey mullets: L. vanbenedenii (Parona and Perugia, 1890); L. szidati Euzet and Suriano, 1977; L. mugilinus (Hargis, 1955); L. chabaudi Euzet and Suriano, 1977; L. macrocolpos Euzet and Suriano, 1977; L. acuminatus Euzet and Suriano, 1977; L. minimus Euzet and Suriano, 1977; L. heteronchus Euzet and Suriano, 1977; L. angustus Euzet and Suriano, 1977; L. imitans Euzet and Suriano, 1977 and L. confusus Euzet and Suriano, 1977. Subsequently Euzet and Sanfilippo ${ }^{83}$ added one new species to the genus, L. parvicirrus Euzet and Sanfilippo 1983. Since the erection of Ligophorus, about 60 new species have been described infecting worldwide mullets. The taxonomic revision of the Atlantic and the Pacific of Ligophorus has been performed by Sarabeev et al. ${ }^{84}$ Thirty-five nominal species of Ligophorus known from the Atlantic and the Pacific waters were covered in this review. Thirty of them, were considered valid, one incertae sedis, one species inquirendae, two junior synonyms and one was transferred to another genus.

The Atlantic and Mediterranean grey mullets, C. labrosus and C. ramado, also harbour another genus of Dactylogyridae, Ergenstrema Paperna, 1964, whose members co-occur on gills with species of Ligophorus. This genus includes only two species, Ergenstrema mugilis Paperna, 1964 and E. labrosi Anderson, 1981 from C. ramado and C. labrosus, respectively ${ }^{85,86}$.
Overstreet ${ }^{87}$ reviewed the taxonomy of Saturnius Manter, 1969, a small hemiurid genus of stomach parasites specific to grey mullets, and described Saturnius papernai Overstreet, 1977 from Mugil cephalus in Bardawil Lagoon, Eastern Mediterranean. This species has been subsequently reported elsewhere in the Mediterranean basin ${ }^{17,20,22,56,76,88-90}$. Dimitrov ${ }^{76}$ provided a redescription of $S$.papernai from the Bulgarian coast of the Black Sea. Two new species of Saturnius (S. minutus BlascoCosta, Pankov, Gibson, Balbuena, Raga, Sarabeev \& Kostadinova, 2006 and Saturnius dimitrovi Blasco-Costa, Pankov, Gibson, Balbuena, Raga, Sarabeev \& Kostadinova, 2006) were described from the Western Mediterranean that raised the number of species of the genus up to three in this region $^{91}$. A new genus and species of hemiurid digenean (Robinia aurata Pankov, Webster, Blasco-Costa, Gibson, Littlewood Balbuena, Kostadinova, 2006) was proposed $^{92}$.

There are several taxonomic and faunistic studies providing information on mullet parasites from the Mediterranean and the Adriatic Sea off Italy ${ }^{20,22,93-101}$ and Montenegro $7,13,14,16,102$. Two new species on nematode and acanthocephalan parasites, Cucullanus bioccai Orecchia and Paggi, 1987 and Acanthogyrus (Acanthosentis) lizae (Orecchia, Paggi, Radujkovic, 1988) Amin, 2005, were described from M. cephalus and C. auratus, respectively in the Adriatic ${ }^{95,102}$

Paperna and co-authors published a set of papers on helminth parasites from the Eastern Mediterranean grey mullets (Israel and Egypt) $)^{2,86,103,104}$. Abu Samak ${ }^{105-107}$ reported three species of Ligophorus from C. ramada in the Mediterranean coastal waters of Egypt. There are also a few papers with helminths records from the Marmara Sea and Turkish Mediterranean ${ }^{108-110}$.

First reports of parasites from the introduced population of $P$. haematocheila in the Azov Sea appeared in papers of Sabodash and Semenenko ${ }^{111,112}$. These authors recorded five parasite species in so-iuy mullets from the Molochny Estuary. Maltsev and co-authors studied parasites of the migrated population of $P$. haematocheila through the 
Kerch Chanel ${ }^{113-115}$. Their taxonomic works were predominantly focused on monogeneans from the so-iuy mullet. Maltsev and Miroshnichenko ${ }^{114,115}$ redescribed Gyrodactylus mugili Zhukov, 1970, G. zhukovi Ling 1962 and G. anguillae Ergens, 1960 and description of a new species Ligophorus gussevi Maltsev and Miroshnichenko, 2004 across different localities in the Azov Sea. However, based on comparative analysis of shape and measurements of sclerotized characters of worms from the so-iuy mullet $L$. gussevi was considered as the junior synonym of Ligophorus pilengas Sarabeev and Balbuena, $2004^{116}$.

Sarabeev and co-authors studied the parasite fauna of $P$. haematocheila and local fish species across localities in the north-western Azov Sea. Sixty-three species of parasites were recorded in the fish studied ${ }^{88,117-122}$. Two new species were described from the so-iuy mullet in the Azov Sea, digenean Bunocotyle constrictus Domnich and Sarabeev, 1999 and monogenean $L$. pilengas. The former species was later considered as the junior synonym of S. papernai ${ }^{90}$. In addition, two species of Ligophorus, L cephali Rubtsova, Balbuena, Sarabeev, Blasco-Costa \& Euzet, 2006 and $L$. mediterraneus Sarabeev, Balbuena \& Euzet, 2005, were described from the Mediterranean and Azov-Black Seas flathead mullet ${ }^{123,124}$. The taxonomic status of $N$. agilis from grey mullets (Mugilidae) across localities in the North-east Atlantic and the North-west Pacific areas was reviewed by Tkach et al. ${ }^{125}$. This review based on morphological features of acanthocephalans showed that there are three different species of Neoechinorhynchus occurring in grey mullet, two of those were recorded in the Atlantic (Neoechinorhynchus (Neoechinorhynchus) agilis and Neoechinorhynchus (Hebesoma) personatus Tkach, Sarabeev et Shvetsova, 2014) and one in the Pacific waters (Neoechinorhynchus (Hebesoma) yamagutii Tkach, Sarabeev et Shvetsova, 2014). Molecular analysis performed on 18S rRNA partial gene sequences has confirmed the species status of $N$. personatus and N. yamagutii ${ }^{126}$.

Míguez-Lozano et al. ${ }^{127}$ provided a detailed description of the helminth communities of $C$. auratus in the Spanish Mediterranean and analysed the role of spatial, temporal, and host variables in shaping the infracommunities. The spatial structure of helminth infracommunities has been found to be determined by a combination of differences in local environmental conditions and the transmission ability of each helminth species along spatial and temporal scales ${ }^{127}$. A quantitative complex analysis of helminth species richness of invasive so-iuy mullet across different native and introduced populations was performed by Sarabeev $^{128}$. This study showed that the helminth diversity was apparently higher in the introduced population of $P$. haematocheila than in those of their native habitat, but this trend was not confirmed when the sampling efforts were controlled for.

The cumulative number of helminth species described in grey mullets is presented in Figure 1. Fewer than 10 species, predominantly large ones, were recorded prior to 1900 . After 1900, the three waves of species description are remarkable in the history of taxonomic studies of helminth parasites. Those are related with papers of Looss ${ }^{30,129}$, Euzet and Suriano ${ }^{82}$ and Blasco-Costa et al. ${ }^{32-}$ 35,91,92,130-132, Sarabeev and co-authors ${ }^{122-124}$. An increase in the number of authors suggests that taxonomic effort has increased since the 1960s reaching the highest number of species described (13) in the first decade of the $21 \mathrm{st}$ century, w hile only one new species was found in the last decade. Since the number of species is limited for any community ${ }^{133}$, we suggest that the decrease in the number of described species observed for the last decade is the consequence of previous intensive taxonomic efforts probably resulted in actual estimation of species richness for the studied area.

Although taxonomic and faunistic studies of helminth parasites from grey mullets have a long history originating from Rudolphi's work in $1819^{12}$ and were frequent enough (counting up to 130 references), they could not be considered as completed. There are two reasons for this. First, regardless of whether the cause is anthropogenic or natural, the environment is changing mostly due to climate change, pollution and introduction of alien species $^{134,135}$. 


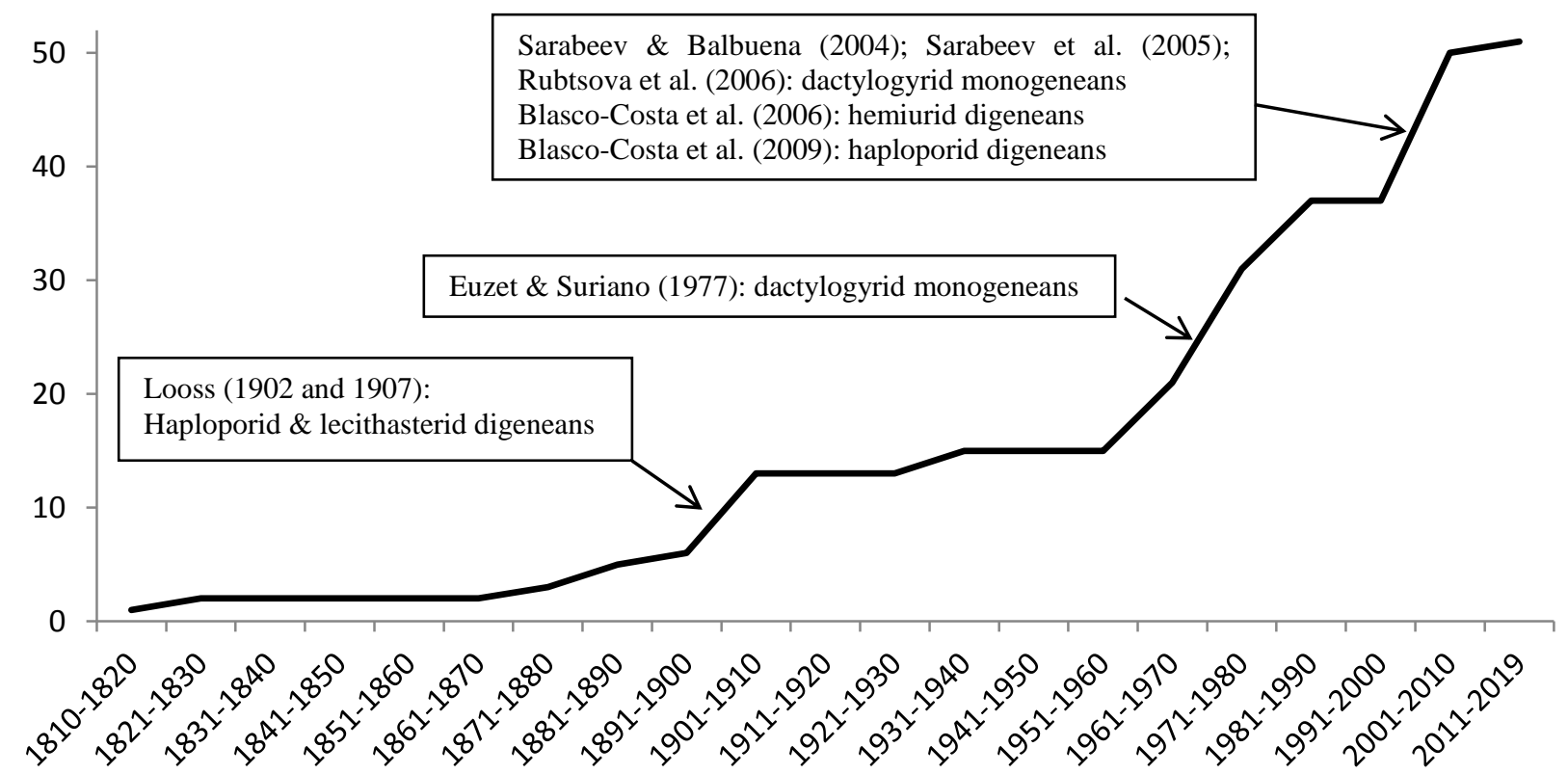

Fig. 1. Cumulative number of helminth species described from grey mullets per decade since 1819 .

Environmental change affects species diversity of aquatic and terrestrial ecosystems resulting in the extinction of species or loss of populations from a particular region, and expansion of invasive or introduced species to new areas ${ }^{134,135}$. Since every fish species usually harbors a number of species, it is no surprising that co-introduced parasites commonly make the trip with their invasive host. The Pacific so-iuy mullet introduced in the Azov-Black Seas provides one example of this. Six helminth species of this invasive host have also invaded the new areas ${ }^{128}$ (Appendix A). In this context, the Lessepsian migration of grey mullets increases the probability of alien helminth species introduced from the Red Sea to the Mediterranean ${ }^{136}$. For instance, Forticulcita glabra and Saccocoelium gohari reported in Eastern Mediterranean localities obviously have a Red Sea origin. Second, application of modern tools and techniques, such as transmission and scanning electron microscopy, molecular and population approaches provides new possibilities for the discovery of new species. The description of two species of mixosporidians of the genus Kudoa from Mediterranean grey mullets ${ }^{137,138}$ is a good example of such research achievement.

\section{Structure of helminth communities from grey mullets in the Mediterranean}

Altogether 104 species of helminth parasites from 53 genera and 29 families have so far been reported in Mediterranean grey mullets; of these, 17 and 3 have been identified to generic and family levels only (Appendix A).

Digeneans represent the most diverse group of helminths in these hosts (53\%) accounting for $29(28 \%)$ and $26(25 \%)$ species at the adult and larval stages, followed by monogeneans, nematodes, acanthocephalans and cestodes (29 (28\%), $12(11 \%), 6(6 \%)$ and $2(2 \%)$ species, respectively) (fig. 2). Specialist parasites accounted for a considerable portion of the parasite communities, including both oioxenic $25(24 \%)$ and stenoxenic $27(26 \%)$ species, vs. $47(45 \%)$ species of generalists; specificity could not be determined for $5(5 \%)$ species. The digestive tract harboured the highest helminth species richness (38 species, 36\%). There is almost equal number of species occurring on gills, the external surface of the body ( 29 species, $28 \%$ ) and in the body cavity, internal organs and tissues (31 species, 30\%).

The number of parasite species reported is unequal in the four Mediterranean geographic areas considered (table 1). The highest number of species was found in the Azov-Black Seas, followed by the Western, Eastern and Central Mediterranean areas. We tend to associate the richest fauna of helminth parasites revealed from the Azov-Black Seas region with the intensity of research efforts. Since the first report of flatworms by Wlassenko ${ }^{36}$ in 1931 , the studies of grey mullet parasites has been quite intensive amounting to over 60 papers. 


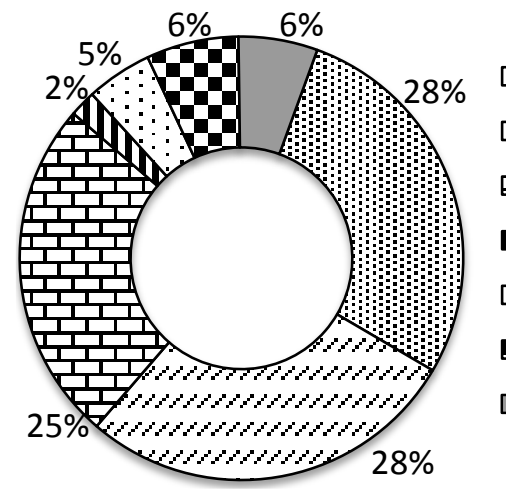

MONOGENEA

口DIGENEA (adults)

ÐDIGENEA (larvae)

п CESTODA (larva)

$\square$ NEMATODA (adults)

DEMATODA (larvae)

$\square$ ACANTHOCEPHALA

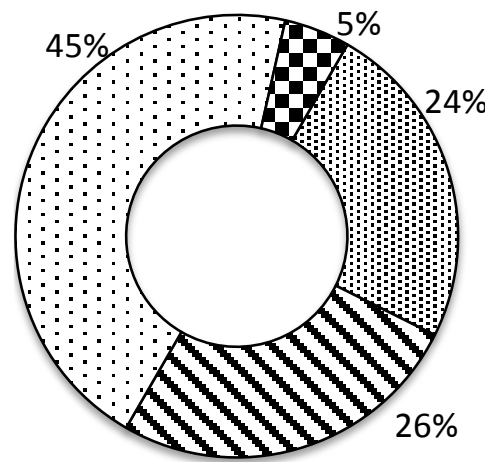

图 Oioxenic

$\boldsymbol{\nabla}$ Stenoxenic

․) Euryxenic

$\square$ Not defined

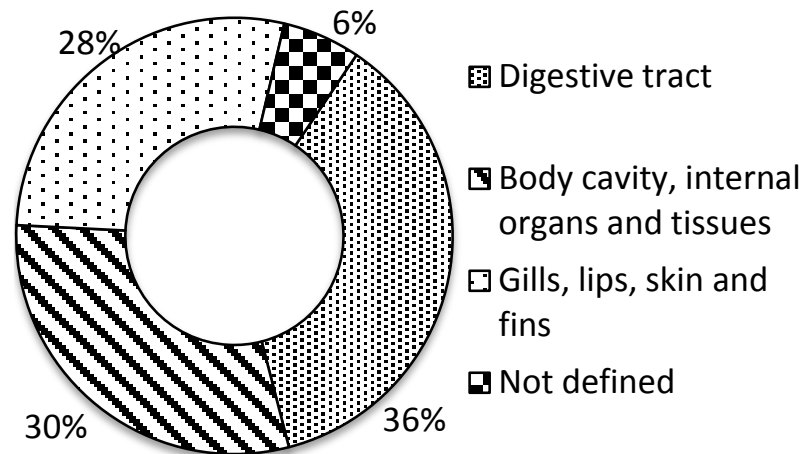

Fig. 2. Structure of the helminth fauna of grey mullets in the Mediterranean region: A - higher-level taxonomic groups and stages, B - host specificity, C - infection site.
Currently, four research teams are active in the Azov-Black Sea, including the Sinop University, Sinop, Turkey; the Institute of Biodiversity and Ecosystem Research, Bulgarian Academy of Sciences, Sofia, Bulgaria; the Institute of Biology of the Southern Seas O. O. Kovalevskoho, the National Academy of Sciences of Ukraine, Sevastopol, Crimea; and the Zaporizhzhia National University, Zaporizhzhia, Ukraine. In contrast, only about 10 papers have reported helminths in the Eastern Mediterranean area across marine localities of Egypt, Israel and Turkey. Similarly, since 1949 fourteen papers were published to discover helminth assemblages of Central Mediterranean region providing data for parasites of the Adriatic Sea and Italian coastal waters (see the previous section).

One interesting finding of the present study is that each geographic region is characterized by a specific set of euryxenic parasites. In contrast to oioxenic and stenoxenic helminths, some of which have been reported in all four areas, euryxenic parasites predominantly known for one or maximum two regions (Appendix A). The exception from this pattern is Ascocotyle longa metacercaria, which were registered in the Western, Eastern Mediterranean and AzovBlack Seas. This finding opens new possibilities to use helminth parasites as bioindicators of fish catches and the stock location.

Table 1 - Number of helminth species reported from different parts of the Mediterranean region: WM - Western Mediterranean; CM - Central Mediterranean; EM - Eastern Mediterranean; AZ-BL - Azov-Black Seas

\begin{tabular}{|l|c|c|c|c|}
\hline Taxon & WM & CM & EM & AZ-BL \\
\hline MONOGENEA & 17 & 17 & 10 & 20 \\
\hline DIGENEA (adults) & 19 & 10 & 13 & 19 \\
\hline DIGENEA (larvae) & 7 & 1 & 7 & 14 \\
\hline CESTODA (larva) & 0 & 0 & 1 & 2 \\
\hline NEMATODA (adults) & 1 & 2 & 2 & 3 \\
\hline NEMATODA (larvae) & 1 & 1 & 1 & 6 \\
\hline ACANTHOCEPHALA & 3 & 3 & 2 & 5 \\
\hline Total & 48 & 34 & 36 & 69 \\
\hline
\end{tabular}

\section{Conclusions}

As a result of all of these, the current list of helminth species recorded from the Azov-Blck
Seas and the Western Mediterranean grey mullets is likely well defined. Marked advances have been made in recent decades, but progress in understanding the helminth 
fauna, particularly from the Eastern and Central Mediterranean regions, will continue to be restricted by the lack of competent taxonomists specialised in specific groups of helminth parasites and the lack of routing monitoring and appropriate samples. Nevertheless, it is evident from our current knowledge that the helminths form a very diverse group of parasites in the grey mullets accounting at list 103 species in the Mediterranean and Azov-Black Seas. A relatively large amount of species (20) identified at generic or family level remains the opportunity for further taxonomic studies. The Eastern Mediterranean remains an intriguing area for the further faunistic research. There are limited studies on parasites from grey mullets in this region and the Lessepsian migration of fish increases the probability of invasion of new parasite species in the Eastern Mediterranean.

\section{Acknowledgements}

This work was partially supported by ASSEMBLE PLUS project, grant agreement No. 730984.

\section{References}

(1) Fish diseases and disorders. Volume 1: protozoan and metazoan infections, 2nd ed.; Woo, P. T. K., Ed.; CABI: Wallingford, 2006.

(2) Paperna, I.; Overstreet, R. M. Parasites and diseases of mullets (Mugilidae). Aquac. grey mullet 1981, 411-493.

(3) Mićković, B.; Nikčević, M.; Hegediš, A.; Regner, S.; Gačić, Z.; Krpo-Ćetković, J. Mullet Fry (Mugilidae) in coastal waters of montenegro, their spatial distribution and migration phenology. Arch. Biol. Sci. 2010, 62 (1), 107-114 DOI: 10.2298/ABS1001107M.

(4) Hung, C.-M.; Shaw, D. The impact of upstream catch and global warming on the grey mullet fishery in Taiwan: a non-cooperative game analysis. Mar. Resour. Econ. 2006, 21 (3), 285300 DOI: $10.1086 / \mathrm{mre} .21 .3 .42629512$.

(5) Whitfield, A. K.; Panfili, J.; Durand, J.-D. D. A global review of the cosmopolitan flathead mullet Mugil cephalus Linnaeus 1758 (Teleostei: Mugilidae), with emphasis on the biology, genetics, ecology and fisheries aspects of this apparent species complex; 2012; Vol. 22.

(6) Froese, R.; Pauly, D. FishBase. World Wide Web electronic publication. www.fishbase.org, version (10/2018) www.fishbase.org.

(7) Radujković, B. M.; Šandić, D.; Šundić, D. Parasitic flatworms (Platyhelminthes: Monogenea, Digenea, Cestoda) of fishes from the Adriatic Sea. Nat. Montenegrina 2014, 13 (1), 7-280 DOI: 10.13140/RG.2.1.1401.5448.

(8) Sabodash, V. M.; Semenenko, L. I. Ecologic-biological base of the acclimatization of far east mullet-pilengas (Mugil so-iuy) in the water basins of Ukraine. Vestnik zoologii. Supplement 6; 1998.

(9) Starushenko, L. I.; Kazansky, A. B. Introduction of mullet haarder (Mugil so-iuy Basilewsky) into the Black Sea and the Sea of Azov. Studies and Reviews; Food and Agriculture Organization of the United Nations: Rome, 1996.

(10) Матишов, Г.; Лужняк, В. Расширение нерестового ареала дальневосточного акклиматизанта пиленгаса Liza haematocheilus (Temminck et Schlegel, 1845) в АзовоЧерноморском бассейне: новые факты из экологии размножения. Доклады Академии наук 2007, 414 (3), 428-429.

(11) Minos, G.; Imsiridou, A.; Economidis, P. S. Liza haematocheilus (Pisces, Mugilidae) in the northern Aegean Sea. In Fish Invasions in the Mediterranean Sea: Change and Renewal; Golani, D., Appelbaum-Golan, B., Eds.; Pensoft Publishers: Sofia-Moscow, 2010; pp 313332.

(12) Rudolphi, C. A. Entozoorum synopsis, cui accedunt mantissa duplex et indices locupletissimi; Sumtibus Augusti Rücker: Berlin, 1819.

(13) Radujković, B. M.; Petrović, Z. Étude de la parasitofaune des muges de l'Adriatique (Chelon labrosus Risso, Liza aurata Risso et Liza saliens Risso - Pisces: Mugilidae) et son influence sur le coefficient de condition des poissons hôtes. Montenegrian Acad. Sci. Arts. Glas. Sect. 
Nat. Sci. 1986, 5, 203-215.

(14) Radujković, B. M.; Raibaut, A. Faune des parasites de poissons marins du Montenegro (Adriatique Sud). In Acta Adriatica. Vol. 30; Radujković, B. M., Raibaut, A., Eds.; Split, 1989; pp 1-324.

(15) Radujković, B. M. Parasites des poissons marins du Monténégro: acanthocéphales. Acta Adriat. 2002, 12 (1), 67-69.

(16) Radujković, B. M. Adriatic Sea mullets parasitofauna. Rev. Rom. Parazitol. 2002, 12 (1), 6769.

(17) Дмитриева, Е. В.; Гаевская, А. В. Паразитологические аспекты марикультуры и интродукции кефалевых рыб в Азово-Черноморском бассейне. Экология моря 2001, 55, 73-78.

(18) Ovcharenko, M. Microparasites of worldwide mullets. Ann. Parasitol. 2015, 61 (4), 229-239 DOI: 10.17420/ap6104.12.

(19) Al-Hadilhri, I.; Daoud, Y. T.; Habash, A. H. Seasonal abundance of Neoechinorhynchus agilis in Mugil hishni from Shatt Al-Arab. J. Gulf Arab. Penins. Stud. 1980, No. 6, 127-139.

(20) Di Cave, D.; Kennedy, C. R.; D’Amelio, S.; Berrilli, F.; Orecchia, P. Struttura della comunità dei metazoi parassiti di Liza ramada (Risso, 1826) nel lago di Burano. Biol. Mar. Mediterr. 1997, 4, 321-323.

(21) Caillot, C.; Morand, S.; Muller-Graf, C.; Faliex, E.; Marchand, B. Parasites of Dicentrarchus labrax, Anguilla anguilla and Mugil cephalus from a pond in Corsica, France. J. Helminthol. Soc. Washingt. 1999, 66, 95-98.

(22) Merella, P.; Garippa, G. Metazoan parasites of grey mullets (Teleostea: Mugilidae) from the Mistras Lagoon (Sardinia, western Mediterranean). Sci. Mar. 2001, 65 (3), 201-206 DOI: 10.3989/scimar.2001.65n3201.

(23) Jithendran, K. P.; Kannappan, S. A short note on heavy infection of acanthocephalan worm (Neoechinorhynchus agilis) in grey mullet, Mugil cephalus. J. Parasit. Dis. 2010, 34 (2), 99101 DOI: 10.1007/s12639-010-0019-y.

(24) Shih, H. H.; Chen, H. Y.; Lee, C. Y. Acanthocephalan fauna of marine fish in Taiwan and the differentiation of three species by ribosomal DNA sequences. Taiwania 2010, 55 (2), 123127.

(25) Eysenhardt, K. W. Einiges über Eingeweidewürmer. In Verhandlungen der Gesellschaft Naturforschender Freunde zu Berlin; Reimer, G. und V. bei G., Ed.; Berlin, 1829; pp 144153.

(26) Vogt, C. Über die Fortpflanzungsorgane einiger ectoparasitischer mariner Trematoden. Zeitschift für Wissenschaftliche, Zool. 1878, 30, 306-342.

(27) Parona, C.; Perugia, A. Dei trematodi delle branchie di pesci Italiani. Atti della Soc. Ligustica di Sci. Nat. e Geogr. 1890, 1, 59-70.

(28) Parona, C.; Perugia, A. Sopra due nuove specie di Trematodi ectoparassiti di pesci marini. Boll. dei Musei di Zool. e Anat. Comp. della R. Unoversitá di Genova 1895, 31, 1-4.

(29) Looss, A. Die Distomenunter familie der Haploporinae. Arch. Parasitol. 1902, 6, 129-143.

(30) Looss, A. Zur Kenntnis der Distomenfamilie Hemiuridae. Zool. Anz. 1907, 31, 585-620.

(31) Nicoll, W. Trematode parasites of fishes in the English Channel. J. Mar. Biol. Assoc. United Kingdom 1914, 10, 466-505.

(32) Blasco-Costa, I.; Montero, F. E.; Balbuena, J. A.; Raga, J. A.; Kostadinova, A. A revision of the Haploporinae Nicoll, 1914 (Digenea: Haploporidae) from mullets (Mugilidae): Dicrogaster Looss, 1902 and Forticulcita Overstreet, 1982. Syst. Parasitol. 2009, 72 (3), 187-206 DOI: 10.1007/s11230-008-9165-3.

(33) Blasco-Costa, I.; Gibson, D. I.; Balbuena, J. A.; Raga, J. A.; Kostadinova, A. A revision of the Haploporinae Nicoll, 1914 (Digenea: Haploporidae) from mullets (Mugilidae): Haploporus Looss, 1902 and Lecithobotrys Looss, 1902. Syst. Parasitol. 2009, 73 (2), 107133 DOI: 10.1007/s11230-009-9175-9.

(34) Blasco-Costa, I.; Montero, F. E.; Gibson, D. I.; Balbuena, J. A.; Raga, J. A.; Kostadinova, A. 
A revision of the Haploporinae Nicoll, 1914 (Digenea: Haploporidae) from mullets (Mugilidae): Saccocoelium Looss, 1902. Syst. Parasitol. 2009, 72 (3), 159-186 DOI: 10.1007/s11230-008-9163-5.

(35) Blasco-Costa, I.; Montero, F. E.; Gibson, D. I.; Balbuena, J. A.; Kostadinova, A. A revision of the Haploporinae Nicoll, 1914 (Digenea: Haploporidae) from mullets (Mugilidae): two new haploporine genera and a key to the genera of the subfamily. Syst. Parasitol. 2009, 72 (3), 207-215 DOI: 10.1007/s11230-008-9164-4.

(36) Власенко, П. В. К фауне паразитических червей рыб Черного моря. Труды Карадагской биологической станиии 1931, 4, 88-135.

(37) Скрябин, К. И. Семейство Haploporidae Nicoll, 1914. In Tрематоды животных и человека. Основы трематодологии. Том 12; Скрябин, К. И., Еd.; АН СССР: М., 1956; pp 7-49.

(38) Yamaguti, S. Systema helminthum. The digenetic trematodes of vertebrates. Vol. I.; Interscience: New York, 1958.

(39) Overstreet, R. M.; Curran, S. S. Family Haploporidae Nicoll, 1914. In Keys to the Trematoda. Vol. 2; Jones, A., Bray, R. A., Gibson, D. I., Eds.; CAB International: Wallingford, 2005; pp 129-165.

(40) Османов, С. У. Материалы к паразитофауне рыб Черного моря. Ученые записки Ленинградского государственного педагогического института 1940, 30, 187-265.

(41) Чернышенко, А. С. Новые гельминты рыб Черного моря. Пращі Одеського Державного Університету 1949, 4 (57), 21-40.

(42) Буцкая, Н. А. Паразитофауна черноморских промысловых рыб предустьевого про-странства Дуная. Труды Ленинградского об-ва естествоиспытателей 1952, 71 (4), $10-26$.

(43) Погорельцева, Т. П. Новые трематоды для рыб Чёрного моря. Труды Карадагской биологической станции 1952, 12, 29-39.

(44) Решетникова, А. В. Паразитофауна кефали Черного моря. Труды Карадагской биологической станщии 1955, 13, 71-95.

(45) Чернышенко, А. С. С. Паразитофауна молоди кефали, зимующей в зимовалах Шаболатского лимана. Tруды Одесского государственного ун-та. Серия биологических наук 1962, 152 (11), 100-104.

(46) Савчук, М. Я. О зараженности кефали Черного моря трематодой Aphanurus stossichi. In Проблемы паразитологии; Наукова Думка: К., 1967; pp 497-498.

(47) Мачкевский, В. К.; Скрябин, В. А. Некоторые особенности гельминтофауны мальков черноморских кефалей. In III Всесоюз. совещ.. по болезням и паразитам рыб; Наука: Л., 1979; pp 70-71.

(48) Солонченко, А. И. Гельминтофауна рыб Азовского моря; Наукова думка: К., 1982.

(49) Солонченко, А. И.; Ткачук, В. П. Зараженность гельминтами кефалей АзовоЧерноморского бассейна. Экология моря 1985, 20, 39-43.

(50) Гаевская, А. В.; Найденова, Н. Н. Паразиты черноморских кефалей. Рыбное хозяйство 1989, 2, 35-36.

(51) Юрахно, В. М. Новые сведения о фауне миксоспоридий рыб Черного моря. Паразитология 1993, 27 (4), 320-326.

(52) Юрахно, В. М. Миксоспоридии рыб Черного моря: систематика, фауна, экология, зоогеография: Автореф. дисс. На соискание канд. биол. наук, Севастополь, 1994.

(53) Дмитриева, Е. В.; Герасев, П. И. Моногенеи рода Ligophorus (Ancyrocephalidae) паразиты черноморских кефалей (Mugilidae). Паразитология 1996, 30 (5), 440-448.

(54) Дмитриева, Е. В. Фауна моногеней дальневосточного пиленгаса (Mugil soiuy) в Черном море. Вестник зоологии 1996, 30 (4-5), 95-97.

(55) Дмитриева, Е. В. Е. В. Моногенеи рыб Черного моря (фауна, экология, зоогеография): Диссертация ... канд. биол. наук: 03.00.18., Севастополь, 1998.

(56) Пронькина, H. В. Особенности формирования гельминтофауны мальков сингиля Liza 
aurata (Risso) в Черном море. Экология моря 2001, No. 58, 50-52.

(57) Корнийчук, Ю. М. Первая находка трематод у вселенца в Черное море - пиленгаса Mugil soiuy Basilewsky (Pisces: Mugilidae). Экология моря 2002, №. 59, 21-22.

(58) Юрахно, В. М.; Мальцев, В. Н. Новые сведения о миксоспоридиях кефалевых рыб в бассейне Атлантического океана. Экология моря 2002, 61, 39-42.

(59) Белофастова, И. П. Acanthosentis (Acanthogyrus) lizae (Acanthocephala, Acanthosentidae) - новый паразит черноморского сингиля (Liza aurata). Вестник зоологии 2003, 37 (3), 42.

(60) Пронькина, Н.В. Белофастова, И. П. Новые данные о нематодах черноморского сингиля Liza aurata (Pisces: Mugilidae). Экология моря 2005, No. 68, 77-82.

(61) Попюк, М. П. Гельминтофауна пелагических рыб прибрежных вод крыма (Чёрное море). Экология моря 2009, №. 78, 75-80.

(62) Гаевская, А. В.; Гусев, А. В.; Делямуре, С. Л.; Донец, 3. С.; Искова, Н. И.; Корнюшин, В. В.; Ковалёва, А. А.; Маргаритов, Н. М.; Маркевич, А. П.; Мордвинова, Т. Н.; et al. Определитель паразитов позвоночных Чёрного и Азовского морей; Наукова Думка: К., 1975.

(63) Gaevskaya, A. New data on trematodes of the families Opecoelidae and Accacoelidae from fishes in Atlantic Ocean and its Seas. Parasitologia 2002, 36 (3), 219-223.

(64) Гаевская, А. В.; Дмитриева, Е. В. Haplosplanchnus pachysomus (Trematoda: Haplosplanchnidae) - паразит кефалей Черного моря. Паразитология 1992, 26 (1), 385388.

(65) Гаевская, А. В.; Дмитриева, Е. В. Трематоды рода Saccocoelium - паразиты рыб Черного моря. Вестник зоологии 1993, 1, 75-78.

(66) Герасев, П. И.; Дмитриева, Е. В.; Гаевская, А. В. Polyclithrum ponticum sp.n. (Monogenea: Gyrodactylidae: Polyclithrinae) с Mugil cephalus из Черного моря и проблема надродовой систематики гиродактилид. Паразитология 2002, 36 (5), 396404.

(67) Dmitrieva, E. V; Gerasev, P. I.; Pron'kina, N. V. Ligophorus llewellyni n. sp. (Monogenea: Ancyrocephalidae) from the redlip mullet Liza haematocheilus (Temminck \& Schlegel) introduced into the Black Sea from the Far East. Syst. Parasitol. 2007, 67 (1), 51-64 DOI: 10.1007/s11230-006-9072-4.

(68) Dmitrieva, E. V; Gerasev, P. I.; Merella, P.; Pugachev, O. N. Redescription of Ligophorus mediterraneus Sarabeev, Balbuena \& Euzet, 2005 (Monogenea: Ancyrocephalidae) with some methodological notes. Syst. Parasitol. 2009, 73 (2), 95-105 DOI: 10.1007/s11230-0099177-7.

(69) Dmitrieva, E. V; Gerasev, P. I.; Merella, P.; Pugachev, O. N. Redescriptions of Ligophorus cephali Rubtsova, Balbuena, Sarabeev, Blasco-Costa \& Euzet, 2006 and L. chabaudi Euzet \& Suriano, 1977 (Monogenea: Ancyrocephalidae), with notes on the functional morphology of the copulatory organ. Syst. Parasitol. 2009, 73 (3), 175-191 DOI: 10.1007/s11230-0099192-8.

(70) Pronkina, N. V.; Dmitrieva, E. V.; Polyakova, T. A.; Popyuk, M. P. The lifecycle of Dichelyne minutus (Rudolphi, 1819) (Nematoda: Cucullanidae) in the estuarine biocenosis of the Black Sea. Russ. J. Mar. Biol. 2017, 43 (2), 148-155 DOI: 10.1134/S1063074017020079.

(71) Гаевская, А. В.; Дмитриева, Е. В.; Корнийчук, Ю. М. Популяционный подход к изучению гельминтов черноморских рыб: возможности и перспективы использования. Морський екологічний журнал 2002, 1, 78-89.

(72) Найденова, Н. Н.; Захалева, В. А. Некоторые болезни кефалевых, камбаловых и других видов рыб при выращивании в морской воде. Бюл. ЦНИИТЭИРХ 1986, No. 1, 3-25.

(73) Гаевская, А. В. Паразитология и патология рыб: Энщиклопедический словарьсправочник; Изд-во ВНИРО: М., 2003.

(74) Гаєвська, А. В.; Гаевская, А. В. Паразитологія та патологія риб: енцииклопедичний 
словник-довідник; Наукова Думка: К., 2004.

(75) Гаевская, А. В. Паразиты и болезни рыб Чёрного и Азовского морей: I - морские, солоноватоводные и проходные рыбы; ЭКОСИ-Гидрофизика: Севастополь, 2012.

(76) Dimitrov, G. I.; Arapoglou, F. K.; Georgiev, B. B. First record of Saturnius papernai Overstreet, 1977 in the Black Sea, with a review of the genus Saturnius Manter, 1969 (Digenea, Bunocotylidae). Syst. Parasitol. 1998, 40, 43-48.

(77) Pankov, P.; Gibson, D. I.; Kostadinova, A. The translocated Liza haematocheila (Teleostei: Mugilidae) as a new host of four species of Saturnius Manter, 1969 (Digenea: Hemiuridae) within its invasive range in the Black Sea. Syst. Parasitol. 2009, 74 (1), 29-39 DOI: 10.1007/s11230-009-9186-6.

(78) Ozturk, T.; Ozer, A. Monogenean Fish Parasites, Their Host Preferences and Seasonal Distributions in the Lower Kizılırmak Delta (Turkey). Turkish J. Fish. Aquat. Sci. 2014, 14 (2), 367-378 DOI: 10.4194/1303-2712-v14_2_07.

(79) Özer, A.; Kırca, D. Y. Parasite fauna of the grey mullet Mugil cephalus L. 1758, and its relationship with some ecological factors in Lower Kizılırmak Delta located by the Black Sea, Turkey. J. Nat. Hist. 2015, 49 (15-16), 933-956 DOI: 10.1080/00222933.2014.979259.

(80) Tepe, Y.; Oğuz, M. C. Nematode and acanthocephalan parasites of marine fish of the eastern Black Sea coasts of Turkey. Turkish J. Zool. 2013, 37 (6), 753-760 DOI: 10.3906/zoo-120618.

(81) Euzet, L.; Combes, C. Contribution à l'étude des Microcotylidae (Monogenea), parasite de Mugil cephalus L. (Teleostei). Parasitol. Sb. vol. jub. B.E. Bychowski 1969, 24, 91-105.

(82) Euzet, L.; Suriano, D. M. Ligophorus n. g. (Monogenea, Ancyrocephalidae) parasite des Mugilidae (Téléostéens) en Méditerranée. Bull. du Muséum Natl. d’Histoire Nat. 3e série, Zool. 1977, 472, 799-821.

(83) Euzet, L.; Sanfilippo, D. Ligophorus parvicirrus n. sp. (Monogenea, Ancyrocephalidae), parasite of Liza ramada (Risso, 1826) (Teleostei, Mugilidae). Ann. Parasitol. Hum. Comp. 1983, 58 (4), 325-335.

(84) Sarabeev, V. L.; Rubtsova, N. Y.; Yang, T.; Balbuena, J. A. Taxonomic revision of the Atlantic and Pacific species of Ligophorus Euzet and Suriano, 1977 (Monogenea: Dactylogyridae) from mullets (Teleostei: Mugilidae) with proposal of a new genus and description of four new species. Vestn. Zool. Suppl. 28 2013, 112.

(85) Anderson, M. Ergenstrema labrosi sp. nov. on the gills of the thick lipped grey mullet Chelon labrosus at Plymouth. J. Mar. Biol. Assoc. United Kingdom 1981, 61, 827-832.

(86) Paperna, I. Parasitic helminths of inland-water fishes in Israel. Isr. J. Zool. 1964, 13 (1), 124.

(87) Overstreet, R. M. A revision of Saturnius Manter, 1969 (Hemiuridae: Bunocotylinae) with descriptions of two new species from the striped mullet. Excert Parasitol. en Mem. del Dr. Eduardo Caballer. Publicaciones Espec. 1977, 4, 273-284.

(88) Domnich, I. F.; Sarabeev, V. L. Trematodes of the genus Bunocotyle (Trematoda, Halipegedae) from the haarder (Mugil so-iuy) acclimatized in Azov sea. Parazitologiya 1999, 33 (1).

(89) Сарабеев, В. Л.; Домнич, И. Ф. Возрастная динамика зараженности дальневосточной кефали пиленгаса (Mugil soiuy) в Молочном лимане Азовского моря. Вестник зоологии, отдельный выпуск «Экологические исследования в Украине» 2000, 14 (2), 612.

(90) Домнич, И. Ф.; Сарабеев, В. Л. Трематоды дальневосточной кефали-пиленгаса (Mugil soiuy) в Азовском море. Вестник зоологии 2000, 34 (3), 7-15.

(91) Blasco-Costa, I.; Pankov, P.; Gibson, D. I.; Balbuena, J. A.; Raga, J. A.; Sarabeev, V. L.; Kostadinova, A. Saturnius minutus n. sp. and S. dimitrovi n. sp. (Digenea: Hemiuridae) from Mugil cephalus L. (Teleostei: Mugilidae), with a multivariate morphological analysis of the Mediterranean species of Saturnius Manter, 1969. Syst. Parasitol. 2006, 65 (1), 77-91 DOI: 10.1007/s11230-006-9043-9. 
(92) Pankov, P.; Webster, B. L.; Blasco-Costa, I.; Gibson, D. I.; Littlewood, D. T. J.; Balbuena, J. A.; Kostadinova, A. Robinia aurata n. g., n. sp. (Digenea: Hemiuridae) from the mugilid Liza aurata with a molecular confirmation of its position within the Hemiuroidea. Parasitology 2006, 133 (2), 217 DOI: 10.1017/S0031182006000126.

(93) Paggi, L.; Orecchia, P.; Di Cave, D. Elmintofauna di specie ittiche eurialine di interesse commerciale del lago di Sabaudia (Latina-Italia). Parassitologia 1988, 30, 126-127.

(94) Paggi, L.; Orecchia, P.; Cancrini, G.; Minervini, R. Aspetti morfologici ed ecologici dei parassiti di alcune specie ittiche di ambiente salmastro (Lago di Saubaudia-Prov. LatinaItalia). Atti della Soc. Ital. delle Sci. Vet. 1979, 33, 279.

(95) Orecchia, P.; Paggi, L. Cucullanus bioccai n. sp. (Nematoda: Cucullanidae), parassita di Mugil cephalus L. Parassitologia 1987, 29 (1), 71-74.

(96) Orecchia, P.; Paggi, L. Aspetti di sistematica e di ecologia degli elminti parassiti di pesci marini studiati presso l'Istituto di Parassitologia dell'Università di Roma. Parassitologia 1978, 20 (1-3), 73-89.

(97) Ferretti, G.; Paggi, L. Ridescrizione di Saccocoelium obesum Looss, 1902 (sin. Saccocoelium tensum Looss, 1902) trematoda parassita di Mugil cephalus. Riv. Parassitol. 1965, 26, 229239.

(98) Palombi, A. I trematodi d'Italia. Parte 1. Trematodi monogenetici. Arch. Zool. Ital. 1949, 34, 203-408.

(99) D’Amelio, S.; Di Cave, D.; Orecchia, P.; Paggi, L. Le comunità dei metazoi parassiti di Liza ramada (Risso, 1826) (Pisces: Mugilidae) nei laghi di Sabaudia (LT) e del Fusaro. Suppl. alla Richerche di Biol. della Selvag. 1996, 24, 671-676.

(100) Culurgioni, J.; Sabatini, A.; De Murtas, R.; Mattiucci, S.; Figus, V. Helminth parasites of fish and shellfish from the Santa Gilla Lagoon in southern Sardinia, Italy. J. Helminthol. 2014, 88 (4), 489-498 DOI: 10.1017/S0022149X13000461.

(101) Culurgioni, J.; Figus, V.; Cabiddu, S.; De Murtas, R.; Cau, A.; Sabatini, A. Larval helminth parasites of fishes and shellfishes from Santa Gilla Lagoon (Sardinia, Western Mediterranean), and their use as bioecological indicators. Estuaries and Coasts 2015, 38 (5), 1505-1519 DOI: 10.1007/s12237-014-9894-2.

(102) Orecchia, P.; Paggi, L.; Radujkovic, B. M. Sur une nouvelle espece d'eocanthocephale Acanthogyrus (Acanthosentis) lizae n. sp. (Gyracanthocephala, Quadrigyridae) parasite de Liza aurata (Risso). Bull. du Museum Natl. d'Histoire Nat. Sect. A Zool. Biol. Ecol. Anim. 1988, 10 (3), 529-534.

(103) Paperna, I. Parasites and diseases of the grey mullet (Mugilidae) with special reference to the seas of the Near East. Aquaculture 1975, 5 (1), 65-80 DOI: 10.1016/0044-8486(75)90018-6.

(104) Dzikowski, R.; Paperna, I.; Diamant, A. Use of fish parasite species richness indices in analyzing anthropogenically impacted coastal marine ecosystems. Helgol. Mar. Res. 2003, 57 (3-4), 220-227 DOI: 10.1007/s10152-003-0138-2.

(105) Abu Samak, O. A.; Hassan, S. H. Microhabitat and distribution of three monogenean parasites on the gills of the mugilid fish, Liza ramado. J. Egypt. Ger. Soc. Zool. 1998, 26 (D), 273-283.

(106) Abu Samak, O. A.; Hassan, S. H. Prevalence and mean intensity of three monogeneans infesting the gills of the mugilid fish Liza ramada. J. Egypt. Ger. Soc. Zool. 1999, 29, 39-48.

(107) Abu Samak, O. A. Studies on egg morphology of Ligophorus imitans and L. parvicirrus (Dactylogyridea: Ancyrocephalidae) and egg development, hatching mechanism and anatomy of the oncomiracidium of L. imitans. J. Egypt. Ger. Soc. Zool. 1997, 23, 181-198.

(108) Aydoğdu, A.; Emre, N.; Emre, Y. Prevalence and intensity of parasitic helminths of thicklip grey mullet Chelon labrosus in hosts in Beymelek Lagoon Lake in Antalya, Turkey, according to season, host size, age, and sex of the host. Turkish J. Zool. 2015, 39, 643-651 DOI: 10.3906/zoo-1403-55.

(109) Oguz, M. C.; Bray, R. a. Digenetic trematodes of some teleost fish off the Mudanya Coast (Sea of Marmara, Turkey). Helminthologia 2006, 43 (2007), 161-167 DOI: 10.2478/s11687- 
006-0030-0.

(110) Oguz, M.; Bray, R. Cestoda and monogenea of some teleost fishes off the Mudanya Coast (Sea of Marmara, Turkey). Helminthologia 2008, 45 (4), 192-195 DOI: 10.2478/s11687008-0038-8.

(111) Сабодаш, В. М.; Семененко, Л. И. Паразитофауна дальневосточного пиленгаса (Mugil soiuy) в водоемах Украины. Вестник зоологии 1994, №. 2, 44-46.

(112) Сабодаш, В. М.; Семененко, Л. И. Экология и интродукция дальневосточной кефали Mugil so-iuy Basilewsky в водоемах Украины. Гидробиологический журнал 1995, 31 (5), 38-45.

(113) Мальцев, В. Н.; Ждамиров, В. Н. О паразитофауне пиленгаса (Mugil soiuy Basilewsky) Керченского пролива. Труды ЮгНИРО 1996, 42, 229-232.

(114) Мирошниченко, А. И.; Мальцев, В. Н. Ligophorus gussevi sp. nov. (Monogenea, Ancyrocephalidae) - новый вид жаберного паразита пиленгаса (Mugil soiuy). In Bonpocbl развития Крыма. Научно-практический дискуссионно-аналитический сборник. Bып. 15. Проблемы инвентаризации крымской биотығ; Дулицкого, А. Н., Вахрушевой, Л. П., Мишнева, В. Г., Ена, В. Г., Евстафьева, И. Л., Ена, А. В., Стенько, Р. П., Мирошниченко, А. И., Еds.; Таврия-Плюс: Симферополь, 2004; pp 186-192.

(115) Мирошниченко, А. И.; Мальцев, В. Н. Новые для Азово-Черноморского бассейна виды гиродактилюсов (Monogenea: Gyrodactylidae) от пиленгаса. Труды ЮгНИРО 1998, 44, 116-125.

(116) Balbuena, J. A.; Rubtsova, N. Y.; Sarabeev, V. L. Ligophorus pilengas Sarabeev \& Balbuena, 2004 (Monogenea: Ancyrocephalidae) is proposed as the senior synonym of $L$. gussevi Miroshnichenko \& Maltsev, 2004. Syst. Parasitol. 2006, 63 (2), 93-96 DOI: 10.1007/s11230-005-9000-z.

(117) Юрахно, В. М.; Домнич, И. Ф.; Сарабеев, В. Л. Первые сведения о находке Myхоbolus najdenova (Protozoa: Cnidospora: Mухоsporea) в Азовском море. Паразитология 1999, No. 2, 218-223.

(118) Домніч, І. Ф.; Сарабєєв, В. Л. Сучасна фауна паразитів риб у північній частині Азовського моря. Вісник Запорізького державного університету. Фізикоматематичні науки. Біологічні науки 2000, №. 1, 224-230.

(119) Домніч, І. Ф.; Сарабєєв, В. Л. Паразитофауна піленгаса (Mugil soiuy) Азовського моря та шляхи іiі формування. Вісник Запорізького державного університету. Фізикоматематичні науки. Біологічні науки 1999, 2 (2), 218-223.

(120) Domnich, I. F.; Sarabeev, V. L. Parasitic fauna structure of the pilengas in the Azov Sea. In Acta parasitol. Vol. 45, abstracts EMOP VIII.; Poznan, 2000; p 268.

(121) Domnich, I. F.; Sarabeev, V. L. Forming of the parasitic fauna of the pilengas in the Azov Sea. In Acta parasitol. Vol . 45, abstracts EMOP VIII.; Poznan, 2000; p 265.

(122) Sarabeev, V. L.; Balbuena, J. A. Ligophorus pilengas n. sp. (Monogenea: Ancyrocephalidae) from the introduced So-iuy mullet, Mugil soiuy (Teleostei: Mugilidae), in the Sea of Azov and the Black Sea. J. Parasitol. 2004, 90 (2), 222-228 DOI: 10.1645/GE-163R.

(123) Rubtsova, N. Y.; Balbuena, J. A.; Sarabeev, V. L.; Blasco-Costa, I.; Euzet, L. Description and morphometrical variability of a new species of Ligophorus and of Ligophorus chabaudi (Monogenea: Dactylogyridae) on Mugil cephalus (Teleostei) from the Mediterranean basin. J. Parasitol. 2006, 92 (3), 486-495 DOI: 10.1645/GE-747R.1.

(124) Sarabeev, V. L.; Balbuena, J. A.; Euzet, L. Taxonomic status of Ligophorus mugilinus (Hargis, 1955) (Monogenea, Ancyrocephalidae), with a description of Ligophorus mediterraneus n. sp. from Mugil cephalus (Teleostei, Mugilidae) from the Mediterranean Basin. J. Parasitol. 2005, 91 (6), 1444-1451 DOI: 10.1645/GE-418R.1.

(125) Tkach, I.; Sarabeev, V.; Shvetsova, L. Taxonomic status of Neoechinorhynchus agilis (Acanthocephala, Neoechinorhynchidae), with a description of two new species of the genus from the Atlantic and Pacific mullets (Teleostei, Mugilidae). Vestn. Zool. 2014, 48 (4), 291306 DOI: 10.2478/vzoo-2014-0035. 
(126) Sarabeev, V. L.; Tkach, I. V.; Sueiro, R. A.; Leiro, J. Molecular data confirm the species status of Neoechinorhynchus personatus and $N$. yamagutii (Acanthocephala, Neoechinorhynchidae) from the Atlantic and Pacific grey mullets (Teleostei: Mugilidae). Vestn. Zool. 2020, 54 (1), 1-10 DOI: 10.15407/zoo2020.01.001.

(127) Míguez-Lozano, R.; Pardo-Carranza, T. V; Blasco-Costa, I.; Balbuena, J. A. Spatial structure of helminth communities in the golden grey mullet, Liza aurata (Actinopterygii: Mugilidae), from the Western Mediterranean. J. Parasitol. 2012, 98 (5), 904-912 DOI: 10.1645/GE2897.1.

(128) Sarabeev, V. L. Helminth species richness of introduced and native grey mullets (Teleostei: Mugilidae). Parasitol. Int. 2015, 64 (4), 6-17 DOI: 10.1016/j.parint.2015.01.001.

(129) Looss, A. Die Distomenunterfamilie der Haploprinae. Arch. Parasitol. 1902, 6, 129-143.

(130) Blasco-Costa, I.; Montero, F. E.; Gibson, D. I.; Balbuena, J. A.; Raga, J. A.; Shvetsova, L. S.; Kostadinova, A. A revision of the species of Saturnius Manter, 1969 (Digenea: Hemiuridae), parasites of mullets (Teleostei: Mugilidae). Syst. Parasitol. 2008, 71 (1), 53-74 DOI: 10.1007/s11230-008-9141-y.

(131) Blasco-Costa, I.; Balbuena, J. a; Raga, J. a; Kostadinova, a; Olson, P. D. Molecules and morphology reveal cryptic variation among digeneans infecting sympatric mullets in the Mediterranean. Parasitology 2010, 137, 287-302 DOI: 10.1017/S0031182009991375.

(132) Blasco-Costa, I.; Balbuena, J. A.; Kostadinova, A.; Olson, P. D. Interrelationships of the Haploporinae (Digenea: Haploporidae): A molecular test of the taxonomic framework based on morphology. Parasitol. Int. 2009, 58 (3), 263-269 DOI: 10.1016/j.parint.2009.03.006.

(133) Walther, B. A.; Morand, S. Comparative performance of species richness estimation methods. Parasitology 1998, 116, 395-405.

(134) Occhipinti-Ambrogi, A. Global change and marine communities: Alien species and climate change. Mar. Pollut. Bull. 2007, 55 (7-9), 342-352 DOI: 10.1016/j.marpolbul.2006.11.014.

(135) Stephens, K. L.; Dantzler-Kyer, M. E.; Patten, M. A.; Souza, L. Differential responses to global change of aquatic and terrestrial invasive species: evidences from a meta-analysis. Ecosphere 2019, 10 (4), e02680 DOI: 10.1002/ecs2.2680.

(136) Torcu, H.; Mater, S. Lessepsian fishes spreading along the coasts of the Mediterranean and the Southern Aegean Sea of Turkey. Turkish J. Zool. 200AD, 24 (2), 139-148.

(137) Yurakhno, V. M.; Ovcharenko, M. O.; Holzer, A. S.; Sarabeev, V. L.; Balbuena, J. A. Kudoa unicapsula n. sp. (Myxosporea: Kudoidae) a parasite of the Mediterranean mullets Liza ramada and L. aurata (Teleostei: Mugilidae). Parasitol. Res. 2007, 101 (6), 1671-1680 DOI: 10.1007/s00436-007-0711-8.

(138) Holzer, A. S.; Blasco-Costa, I.; Sarabeev, V. L.; Ovcharenko, M. O.; Balbuena, J. A. Kudoa trifolia sp. n. - Molecular phylogeny suggests a new spore morphology and unusual tissue location for a well-known genus. J. Fish Dis. 2006, 29 (12), 743-755 DOI: 10.1111/j.13652761.2006.00770.x. 
Appendix A. Helminths species recorded in grey mullets in the Mediterranean with information on host specificity, site of infection and distribution range

\begin{tabular}{|c|c|c|c|}
\hline Helminth species* & $\begin{array}{l}\text { Speci- } \\
\text { ficity** }\end{array}$ & Infection site & $\begin{array}{c}\text { Geographic } \\
\text { area*** }\end{array}$ \\
\hline \multicolumn{4}{|l|}{ MONOGENEA } \\
\hline \multicolumn{4}{|l|}{ Dactylogyridae Bychowsky, 1933} \\
\hline 1. Ligophorus acuminatus Euzet et Suriano, 1977 & $\mathrm{O}$ & Gills & WM, CM, AZ-BL \\
\hline 2. Ligophorus angustus Euzet et Suriano, 1977 & $\mathrm{O}$ & Gills & WM, CM, EM \\
\hline $\begin{array}{l}\text { 3. Ligophorus cephali Rubtsova, Balbuena, Sarabeev, } \\
\text { Blasco-Costa \& Euzet, } 2006\end{array}$ & $\mathrm{O}$ & Gills & WM, AZ-BL \\
\hline 4. Ligophorus chabaudi Euzet \& Suriano, 1977 & $\mathrm{O}$ & Gills & WM, CM \\
\hline 5. Ligophorus confusus Euzet et Suriano, 1977 & $\mathrm{O}$ & Gills & WM, CM, EM \\
\hline 6. Ligophorus heteronchus Euzet et Suriano, 1977 & $\mathrm{O}$ & Gills & WM, CM, AZ-BL \\
\hline 7. Ligophorus imitans Euzet et Suriano, 1977 & $\mathrm{O}$ & Gills & WM, CM, EM \\
\hline 8. Ligophorus kaohsianghsieni (Gussev, 1962) ${ }^{\mathrm{CO}}$ & $\mathrm{O}$ & Gills & AZ-BL \\
\hline $\begin{array}{l}\text { 9. Ligophorus llewellyni Dmitrieva, Gerasev \& Pron'kina, } \\
2007 \text { CO }\end{array}$ & $\mathrm{O}$ & Gills & AZ-BL \\
\hline 10. Ligophorus macrocolpos Euzet et Suriano, 1977 & $\mathrm{O}$ & Gills & WM, CM, AZ-BL \\
\hline $\begin{array}{l}\text { 11. Ligophorus mediterraneus Sarabeev, Balbuena \& Euzet, } \\
2005\end{array}$ & $\mathrm{O}$ & Gills & WM, CM, AZ-BL \\
\hline 12. Ligophorus minimus Euzet et Suriano, 1977 & $\mathrm{O}$ & Gills & WM, CM, AZ-BL \\
\hline 13. Ligophorus parvicirrus Euzet et Sanfilippo, 1983 & $\mathrm{O}$ & Gills & WM, CM, EM \\
\hline 14. Ligophorus pilengas Sarabeev et Balbuena, $2004^{\mathrm{CO}}$ & $\mathrm{O}$ & Gills & AZ-BL \\
\hline 15. Ligophorus szidati Euzet et Suriano, 1977 & $\mathrm{O}$ & Gills & $\begin{array}{l}\text { WM, CM, EM, } \\
\text { AZ-BL }\end{array}$ \\
\hline 16. Ligophorus vanbenedenii (Parona \& Perugia, 1890) & $\mathrm{O}$ & Gills & $\begin{array}{l}\text { WM, CM, EM, } \\
\text { AZ-BL }\end{array}$ \\
\hline 17. Ergenstrema labrosi Anderson 1981 & $\mathrm{O}$ & Gills & WM, CM \\
\hline 18. Ergenstrema mugilis Paperna, 1964 & $\mathrm{O}$ & Gills & WM, CM, EM \\
\hline \multicolumn{4}{|l|}{ Gyrodactylidae van Beneden \& Hesse, 1863} \\
\hline 19. Gyrodactylus mugili Zhukov, $1970^{\mathrm{CO}}$ & $\mathrm{O}$ & Gills, skin, fins & AZ-BL \\
\hline 20. G. zhukovi Ling, $1962^{\mathrm{CO}}$ & $\mathrm{O}$ & Gills, skin, fins & AZ-BL \\
\hline 21. Gyrodactylus anguillae Ergens, 1960 & $\mathrm{~N}$ & Gills & AZ-BL \\
\hline 22. G. alviga Dmitrieva \& Gerasev, 2000 & $\mathrm{E}$ & Gills & AZ-BL \\
\hline 23. Polyclithrum mugilini Rogers, 1967 & $\mathrm{O}$ & Gills & AZ-BL \\
\hline $\begin{array}{l}\text { 24. Polyclithrum ponticum Gerasev, Dmitrieva \& } \\
\text { Gaevskaya, } 2002\end{array}$ & $\mathrm{O}$ & Gills & AZ-BL \\
\hline \multicolumn{4}{|l|}{ Microcotylidae Taschenberg, 1879} \\
\hline 25. Metamicrocotyla cephalus (Azim, 1939) & $\mathrm{S}$ & Gills & WM, CM, EM \\
\hline 26. Solostamenides mugilis (Vogt, 1878) & $S$ & Gills & $\begin{array}{l}\text { WM, CM, EM, } \\
\text { AZ-BL }\end{array}$ \\
\hline 27. Solostamenides $\mathrm{sp} .1^{\mathrm{CO}}$ & $\mathrm{S}$ & Gills & AZ-BL \\
\hline 28. Solostamenides sp. 2 & $\mathrm{~N}$ & Gills & AZ-BL \\
\hline \multicolumn{4}{|l|}{ Capsalidae Baird, 1873} \\
\hline 29. Benedenia monticelii (Parona et Perugia, 1895) & $\mathrm{S}$ & Gills, lips, skin & CM, EM \\
\hline \multicolumn{4}{|l|}{ DIGENEA (adults) } \\
\hline \multicolumn{4}{|l|}{ Haploporidae Nicoll, 1914} \\
\hline 30. Dicrogaster contracta Looss, 1902 & $\mathrm{~S}$ & Intestine & $\begin{array}{l}\text { WM, CM, EM, } \\
\text { AZ-BL }\end{array}$ \\
\hline 31. Dicrogaster perpusilla Looss, 1902 & $\mathrm{~S}$ & Intestine & WM, CM, EM \\
\hline $\begin{array}{l}\text { 32. Forticulcita gibsoni Blasco-Costa, Montero, Balbuena, } \\
\text { Raga \& Kostadinova, } 2009\end{array}$ & $\mathrm{~S}$ & Intestine & WM \\
\hline 33. Forticulcita glabra Overstreet, 1982 & S & Intestine & EM \\
\hline 34. Haploporus benedenii (Stossich, 1887) & $\mathrm{S}$ & Intestine & $\begin{array}{l}\text { WM, CM, EM, } \\
\text { AZ-BL }\end{array}$ \\
\hline 35. Lecithobotrys putrescens Looss, 1902 & $\mathrm{~S}$ & Intestine & $\begin{array}{l}\text { WM, CM, EM, } \\
\text { AZ-BL }\end{array}$ \\
\hline $\begin{array}{l}\text { 36. Ragaia lizae Blasco-Costa, Montero, Gibson, Balbuena, } \\
\text { Kostadinova, } 2009\end{array}$ & $\mathrm{O}$ & Intestine & WM \\
\hline 37. Saccocoelium brayi Blasco-Costa, Balbuena, Raga, & $\mathrm{S}$ & Pyloric caeca & WM \\
\hline
\end{tabular}




\begin{tabular}{|c|c|c|c|}
\hline Helminth species* & $\begin{array}{c}\text { Speci- } \\
\text { ficity** }\end{array}$ & Infection site & $\begin{array}{c}\text { Geographic } \\
\text { area*** }\end{array}$ \\
\hline \multicolumn{4}{|l|}{ Kostadinova \& Olson, 2009} \\
\hline $\begin{array}{l}\text { 38. Saccocoelium cephali Blasco-Costa, Montero, Gibson, } \\
\text { Balbuena, Raga \& Kostadinova, } 2009\end{array}$ & $\mathrm{~S}$ & Intestine & WM, AZ-BL \\
\hline $\begin{array}{l}\text { 39. Saccocoelium currani Blasco-Costa, Montero, Gibson, } \\
\text { Balbuena, Raga \& Kostadinova, } 2009\end{array}$ & $\mathrm{~S}$ & Intestine & WM \\
\hline $\begin{array}{l}\text { 40. Saccocoelium gohari Ramadan, Saoud, Ashour \& } \\
\text { Mansour, } 1989\end{array}$ & $\mathrm{~S}$ & Intestine & EM \\
\hline 41. Saccocoelium obesum Looss, 1902 & $\mathrm{~S}$ & Intestine & $\begin{array}{c}\text { WM, CM, EM, } \\
\text { AZ-BL }\end{array}$ \\
\hline 42. Saccocoelium tensum Looss, 1902 & $\mathrm{~S}$ & Intestine & $\begin{array}{l}\text { WM, CM, EM, } \\
\text { AZ-BL }\end{array}$ \\
\hline \multicolumn{4}{|l|}{ Haplosplanchnidae Poche, 1926} \\
\hline 43. Haplosplanchnus pachysomus (Eysenhardt, 1829) & $\mathrm{S}$ & Intestine & $\begin{array}{l}\text { WM, CM, EM, } \\
\text { AZ-BL }\end{array}$ \\
\hline 44. Schikhobalotrema sparisoma (Manter, 1937) & $\mathrm{S}$ & Intestine & WM, AZ-BL \\
\hline 45. Schikhobalotrema sp. & $\mathrm{N}$ & Intestine & CM, EM \\
\hline \multicolumn{4}{|l|}{$\begin{array}{r}\text { Hemiuridae Looss, } 1899 \\
\end{array}$} \\
\hline 46. Bunocotyle cingulata Odhner, 1928 & $\mathrm{E}$ & Intestine & AZ-BL \\
\hline 47. Aphanurus stossichii (Monticelli, 1891) & $\mathrm{E}$ & Oesophagus, stomach & AZ-BL \\
\hline 48. Hemiurus appendiculatus (Rudolphi, 1802) & $\mathrm{E}$ & Stomach, intestine & CM, AZ-BL \\
\hline $\begin{array}{l}\text { 49. Robinia aurata Pankov, Webster, Blasco-Costa, Gibson, } \\
\text { Littlewood Balbuena, Kostadinova, } 2006\end{array}$ & $\mathrm{~S}$ & Stomach & WM \\
\hline $\begin{array}{l}\text { 50. Saturnius minutus Blasco-Costa, Pankov, Gibson, } \\
\text { Balbuena, Raga, Sarabeev \& Kostadinova, } 2006\end{array}$ & S & Stomach & WM, AZ-BL \\
\hline 51. Saturnius papernai Overstreet, 1977 & $\mathrm{~S}$ & Stomach & WM, EM, AZ-BL \\
\hline $\begin{array}{l}\text { 52. Saturnius dimitrovi Blasco-Costa, Pankov, Gibson, } \\
\text { Balbuena, Raga, Sarabeev \& Kostadinova, } 2006\end{array}$ & $\mathrm{~S}$ & Stomach & WM, AZ-BL \\
\hline 53. Saturnius sp. & $\mathrm{N}$ & Stomach & AZ-BL \\
\hline \multicolumn{4}{|l|}{ Lecithasteridae Odhner, 1905} \\
\hline 54. Aponurus tschugunovi Issatschikov, 1928 & $\mathrm{E}$ & Intestine & AZ-BL \\
\hline 55. Lecithaster confusus Odhner, 1905 & $\mathrm{~S}$ & Intestine & $\begin{array}{l}\text { WM, CM, EM, } \\
\text { AZ-BL }\end{array}$ \\
\hline 56. Lecithaster galeatus Looss, 1907 & $\mathrm{~S}$ & Intestine & EM, AZ-BL \\
\hline \multicolumn{4}{|l|}{ Aporocotylidae Odhner, 1912} \\
\hline 57. Cardicola mugilis Yamaguti, 1970 & $\mathrm{O}$ & $\begin{array}{l}\text { Blood vessels of heart } \\
\text { and gills }\end{array}$ & WM \\
\hline \multicolumn{4}{|l|}{ Opecoelidae Ozaki, 1925} \\
\hline 58. Helicometra fasciata (Rudolphi, 1819) & $\mathrm{E}$ & Intestine & AZ-BL \\
\hline \multicolumn{4}{|l|}{ DIGENEA (larvae) } \\
\hline \multicolumn{4}{|l|}{ Acanthocolpidae Lühe,1906 } \\
\hline 59. Acanthocolpidae gen. sp. & $\mathrm{E}$ & Muscles & WM \\
\hline \multicolumn{4}{|l|}{ Bucephalidae Poche, 1907} \\
\hline 60. Rhipidocotyle sp. & $\mathrm{E}$ & $\begin{array}{l}\text { Heart, liver, spleen, } \\
\text { kidney }\end{array}$ & WM \\
\hline 61. Bucephalus minimus (Stossich, 1887) & $\mathrm{E}$ & Heart, liver, spleen & WM \\
\hline 62. Bucephalus sp. & $\mathrm{E}$ & $\mathrm{N}$ & EM \\
\hline \multicolumn{4}{|l|}{ Diplostomidae Poirier, 1886} \\
\hline 63. Diplostomum spathaceum (Rudolphi, 1819) & $\mathrm{E}$ & Eye lenses & AZ-BL \\
\hline 64. Diplostomum spp. & $\mathrm{E}$ & Eye lenses & AZ-BL \\
\hline 65. Posthodiplostomum brevicaudatum (Nordmann, 1832) & $\mathrm{E}$ & Eyes & AZ-BL \\
\hline 66. Tylodelphys clavata (Nordmann, 1832) & $E$ & Vitreous humor of eye & AZ-BL \\
\hline \multicolumn{4}{|l|}{ Echinostomatidae Looss, 1899} \\
\hline 67. Stephanoprora sp. (as Mesorchis sp.) & $\mathrm{E}$ & Gills filaments & AZ-BL \\
\hline \multicolumn{4}{|l|}{ Cryptogonimidae Ward, 1917} \\
\hline 68. Timoniella imbutiforme (Molin, 1859) & $\mathrm{E}$ & $\begin{array}{l}\text { Pharyngeal pad, } \\
\text { muscles, eyes, }\end{array}$ & AZ-BL \\
\hline \multicolumn{4}{|l|}{ Clinostomatidae Lühe, 1901} \\
\hline 69. Clinostomum sp. (as Clinostomum piscidium) & $\mathrm{E}$ & Skin, abdominal cavity & AZ-BL \\
\hline Heterophyidae Odhner, 1914 & & & \\
\hline
\end{tabular}




\begin{tabular}{|c|c|c|c|}
\hline Helminth species* & $\begin{array}{c}\text { Speci- } \\
\text { ficity** }\end{array}$ & Infection site & $\begin{array}{c}\text { Geographic } \\
\text { area }_{* * *}\end{array}$ \\
\hline 70. Ascocotyle coleostoma (Looss, 1896) & $\mathrm{E}$ & Gills & AZ-BL \\
\hline 71. Ascocotyle longa Ransom, 1920 & $\mathrm{E}$ & $\begin{array}{c}\text { Pharyngeal pad, } \\
\text { muscles, esophagus, } \\
\text { intestine, heart, liver, } \\
\text { spleen, kidney }\end{array}$ & WM, EM, AZ-BL \\
\hline 72. Ascocotyle sinoecum (Ciurea, 1933) & $\mathrm{E}$ & $\begin{array}{c}\text { Pharyngeal pad, } \\
\text { esophagus, intestine, } \\
\text { liver }\end{array}$ & AZ-BL \\
\hline 73. Cryptocotyle concavum (Creplin, 1825) & $\mathrm{E}$ & Gills filaments & AZ-BL \\
\hline 74. Cryptocotyle sp. & $\mathrm{E}$ & $\mathrm{N}$ & EM \\
\hline 75. Galactosomum sp. & $\mathrm{E}$ & Brain & WM \\
\hline 76. Galactosomum timondavidi Pearson \& Prévot, 1971 & $\mathrm{E}$ & Brain & WM \\
\hline 77. Haplorchis sp. & $\mathrm{E}$ & $\mathrm{N}$ & EM \\
\hline 78. Heterophyes aequalis Looss, 1902 & $\mathrm{E}$ & $\begin{array}{c}\text { Pharyngeal pad, } \\
\text { muscles, esophagus, } \\
\text { intestine, heart, liver, } \\
\text { spleen }\end{array}$ & EM \\
\hline 79. Heterophyes dispar Looss, 1902 & $\mathrm{E}$ & $\begin{array}{c}\text { Pharyngeal pad, } \\
\text { muscles, esophagus, } \\
\text { intestine, heart, liver, } \\
\text { spleen }\end{array}$ & EM \\
\hline 80. Heterophyes heterophyes Siebold, 1852 & $\mathrm{E}$ & $\begin{array}{c}\text { Pharyngeal pad, } \\
\text { muscles, esophagus, } \\
\text { intestine, heart, liver, } \\
\text { spleen }\end{array}$ & EM, CM \\
\hline 81. Pygidiopsis genata Looss, 1907 & $\mathrm{E}$ & $\begin{array}{c}\text { Pharyngeal pad, } \\
\text { esophagus, intestine, } \\
\text { heart, liver, spleen }\end{array}$ & AZ-BL \\
\hline 82. Stictodora sawakinensis Looss, 1899 & $\mathrm{E}$ & $\mathrm{N}$ & EM \\
\hline \multicolumn{4}{|l|}{ Microphallidae Travassos, 1920} \\
\hline 83. Microphallidae gen. sp. & $\mathrm{E}$ & $\mathrm{N}$ & AZ-BL \\
\hline \multicolumn{4}{|l|}{ Strigeidae Railliet, 1919} \\
\hline 84. Cardiocephalus longicollis (Rudolphi, 1819) & $\mathrm{E}$ & Brain & WM, AZ-BL \\
\hline \multicolumn{4}{|l|}{ CESTODA (larva) } \\
\hline \multicolumn{4}{|l|}{ Diphyllobothriidae Lühe, 1910} \\
\hline 85. Ligula $\mathrm{sp}$. & E & Abdominal cavity & AZ-BL \\
\hline \multicolumn{4}{|l|}{ Tetraphyllidea } \\
\hline 86. Tetraphyllidea gen.sp. & E & Intestine & EM, AZ-BL \\
\hline \multicolumn{4}{|l|}{$\begin{array}{r}\text { NEMATODA } \\
\end{array}$} \\
\hline \multicolumn{4}{|l|}{ Acuariidae Railliet, Henry \& Sisoff, 1912 (larvae) } \\
\hline 87. Paracuaria adunca (Creplin, 1846) & $\mathrm{E}$ & Mesentery & AZ-BL \\
\hline 88. Cosmocephalus obvelatus (Creplin, 1825) & $\mathrm{E}$ & $\begin{array}{c}\text { Abdominal cavity, } \\
\text { intestine }\end{array}$ & AZ-BL \\
\hline \multicolumn{4}{|l|}{ Anisakidae (Railliet \& Henry, 1912) (larvae) } \\
\hline 89. Contracoecum rudolphii (Hartwich, 1964) & $\mathrm{E}$ & Gall bladder & AZ-BL \\
\hline 90. Contracaecum microcephalum (Rudolphi, 1809) & $\mathrm{E}$ & $\begin{array}{c}\text { Abdominal cavity, } \\
\text { mesentery }\end{array}$ & AZ-BL \\
\hline 91. Contracaecum $\mathrm{sp}$. & $\mathrm{E}$ & $\begin{array}{c}\text { Abdominal cavity, } \\
\text { mesentery }\end{array}$ & $\begin{array}{c}\text { WM, CM, EM, } \\
\text { AZ-BL }\end{array}$ \\
\hline 92. Hysterothylacium aduncum (Rudolphi, 1802) & $\mathrm{E}$ & $\begin{array}{l}\text { Abdominal cavity, } \\
\text { liver, mesentery }\end{array}$ & AZ-BL \\
\hline \multicolumn{4}{|l|}{ Capillariidae Railliet, 1915} \\
\hline 93. Capillaria $\mathrm{sp}$. & $\mathrm{E}$ & Digestive tract & $\mathrm{CM}$ \\
\hline 94. Pseudocapillaria tomentosa (Dujardin, 1843) & $\mathrm{E}$ & Intestine & AZ-BL \\
\hline \multicolumn{4}{|l|}{ Cucullanidae Cobbold, 1864} \\
\hline 95. Cucullanus bioccai Orecchia \& Paggi 1987 & $\mathrm{~S}$ & Intestine & WM, CM, EM \\
\hline 96. Dichelyne minutus (Rudolphi, 1819) (larva) & $\mathrm{E}$ & $\mathrm{N}$ & AZ-BL \\
\hline Philometridae Baylis \& Daubney, 1926 & & & \\
\hline 97. Philometra tauridica Ivashkin, Naidenova, Kovalev & $\mathrm{E}$ & Abdominal cavity & AZ-BL \\
\hline
\end{tabular}




\begin{tabular}{|c|c|c|c|}
\hline Helminth species* & $\begin{array}{l}\text { Speci- } \\
\text { ficity*** }\end{array}$ & Infection site & $\begin{array}{l}\text { Geographic } \\
\text { area*** }\end{array}$ \\
\hline \multicolumn{4}{|l|}{ Khromova, 1971} \\
\hline 98. Philometra sp. & $\mathrm{N}$ & Esophagus & EM, AZ-BL \\
\hline \multicolumn{4}{|l|}{ ACANTHOCEPHALA } \\
\hline \multicolumn{4}{|l|}{ Neoechinorhynchidae Ward, 1917} \\
\hline 99. Floridosentis elongata $\mathrm{W}$ ard, 1953 & $\mathrm{E}$ & Intestine & AZ-BL \\
\hline 100.Neoechinorhynchus agilis (Rudolphi, 1819) & $\mathrm{S}$ & Intestine & WM, CM, EM \\
\hline $\begin{array}{l}\text { 101. Neoechinorhynchus personatus Tkach, Sarabeev \& } \\
\text { Shvetsova, } 2014\end{array}$ & $\mathrm{~S}$ & & $\begin{array}{l}\text { WM, CM, EM, } \\
\text { AZ-BL }\end{array}$ \\
\hline \multicolumn{4}{|l|}{ Quadrigyridae Van Cleave, 1920} \\
\hline 102.Acanthogyrus (Acanthosentis) adriaticus Amin, 2005 & $\mathrm{O}$ & Intestine & WM, CM, AZ-BL \\
\hline \multicolumn{4}{|l|}{ Illiosentidae Golvan, 1960} \\
\hline 103.Telosentis exiguus Von Linstow, 1901 & $\mathrm{E}$ & Intestine & AZ-BL \\
\hline Polymorphidae Meyer, 1931 (cystacant) & & & \\
\hline 104.Southwellina hispida (Van Cleave, 1925) & $\mathrm{E}$ & Abdominal cavity & AZ-BL \\
\hline
\end{tabular}

Footnotes: *The species status and taxonomic affinities follow the WoRMS data base (http://www.marinespecies.org/); ${ }^{\mathrm{CO}}$ co-introduced species of helminth parasites reported in Planiliza haematocheila after the host translocation from the Sea of Japan to the Azov-Black Sea;

**Specificity abbreviations: O, oioxenic; S, stenoxenic; E, euryxenic; N, not determined.

***WM: Western Mediterranean; CM: Central Mediterranean; EM: Eastern Mediterranean; AZ-BL: Azov-Black Seas 